\title{
GRAVIMETRIC DENSIFICATION IN THE STATE OF SÃO PAULO AIMING A GEOID MODEL
}

\author{
Gabriel do Nascimento Guimarães ${ }^{1}$, Ana Cristina Oliveira Cancoro de Matos $^{2}$ and Denizar Blitzkow²
}

\begin{abstract}
Gravity data coverage is quite complete in São Paulo state for a 5' resolution. In addition, field works have been conducted to fill in gaps around the state. These efforts are the results of the Fundação de Amparo à Pesquisa do Estado de São Paulo (FAPESP) Thematic Project that seeks to achieve the establishment of a geoid model, a height system, and the study of mean sea level. This paper presents a comparison between two geoidal height models; the first with information available up to 2008 (beginning of the project) and the second including all data collected. Both models have been derived using the modified Stokes integral through the FFT technique. The SHGEO package was used to derive the Helmert gravity anomalies, while the EGM2008 model was selected as a reference geopotential field restricted to degree and order 150, to obtain the long and medium wavelength components. The model was validated using the geoidal heights from 170 GPS observations on Bench Marks of the spirit leveling network. The corresponding height anomalies derived from recent geopotential models (GO_CONS_GCF_2_TIM_R2, GOCO02S and ElGEN-6C) were also compared with the same quantities at the points of leveling, besides the official Brazilian model, MAPGE02010. The findings showed that GE0IDSP2011 displayed better consistency with respect for the GPS/leveling than GEOIDSP2008 and the geopotential models.
\end{abstract}

Keywords: geodesy, geoid, geopotential model.

RESUMO. 0 estado de São Paulo possui uma cobertura bastante completa de dados gravimétricos para uma resolução de 5'. Além disso, trabalhos de campo estão sendo realizados com o objetivo de preencher os vazios no entorno do estado. Os recentes esforços nos levantamentos são devido ao Projeto Temático da FAPESP que tem, entre outras finalidades o estabelecimento de um modelo geoidal, além do estudo sobre sistemas de altitude e monitoramento do nível médio dos mares. Este artigo apresenta a comparação entre dois modelos de alturas geoidais; o primeiro com informações disponíveis até 2008 (fase inicial do projeto) e o segundo incluindo os dados coletados até o momento. Ambos os modelos foram calculados utilizando a integral modificada de Stokes por meio da técnica FFT. 0 pacote computacional SHGEO foi empregado para determinar as anomalias de gravidade de Helmert, enquanto o modelo do geopotencial EGM2008 restrito até grau e ordem 150 foi selecionado para obter as componentes de longo e médio comprimento de onda. Os modelos foram validados a partir da comparação das alturas geoidais em 170 marcos da rede de nivelamento onde observações GPS foram conduzidas. As anomalias de altura dos modelos mais recentes do geopotencial (G0_CONS_GCF_2_TIM_R2, GOC002S e ElGEN-6C) também foram comparadas com as mesmas grandezas nos pontos de nivelamento, além do modelo oficial brasileiro, o MAPGE02010. Os resultados mostraram melhor consistência na comparação com os pontos GPS/nivelamento do modelo GEOIDSP2011 em relação ao GEOIDSP2008 e os modelos do geopotencial.

Palavras-chave: geodésia, geoide, modelo do geopotencial.

\footnotetext{
${ }^{1}$ Universidade Federal de Uberlândia, Instituto de Geografia, Campus Monte Carmelo. Av. Goiás, n² 2000, 38500-000 Monte Carmelo, MG, Brazil. Phone: +55(34) 3482-8751 - E-mail: gabrielguimaraes33@hotmail.com

2Universidade de São Paulo, Departamento de Engenharia de Transportes, Laboratório de Topografia e Geodésia, Av. Prof. Almeida Prado, tv. 2, n 83, Caixa Postal 61548, 05424-970 São Paulo, SP, Brazil. Phone: +55(11)3091-5439 - E-mails: acocmatos@gmail.com; dblitzko@usp.br
} 


\section{INTRODUCTION}

Gravimetric information plays a fundamental role in certain areas of the sciences, such as, for instance, in Geology in studies of geological structures, in Geophysics in mineral prospection and models of the crust, and in Geodesy. In this latter, gravimetry is determinant for calculating the geoidal model, which means the shape of the Earth. On the other hand, the global models of geopotential, the set of coefficients of the gravitational potential function of the Earth, developed in a series of spherical harmonic functions, contribute decisively with the gravimetric data. As a matter of fact, the geopotential models provide knowledge of the long wavelengths of the gravitational field, whereas gravimetry allows us to detail the short wavelengths.

Brazil has a gravimetric network linked to the Brazilian Geodesic System ("SGB") under the responsibility of the IBGE (Brazilian Institute of Geography and Statistics). However, this network lacks gravimetric measurements in various regions. Added to this context is the SBG altimetric network, and recently the new adjustment of the normal-orthometric altitudes was made available (IBGE, 2011). The High Precision Altimetric Network is connected to the Imbituba tide gauge. Given the impossibility of performing geometric levelling to the north of the Amazon river, one portion of the network in the state of Amapá is linked to the Santana tide gauge. It is worth stressing that many levelling lines do not have values of acceleration of gravity associated to the normal-orthometric altitudes. If, together with the levelling, the value of acceleration of gravity is obtained, we obtain the geopotential figure, a uniform magnitude that has real physical significance in the definition of altitudes.

At present, in São Paulo State, some engineering works are being carried out: the duplication of highways, large-scale roadbuilding projects, such as the Rodanel ring road, expansion of the São Paulo subway, and a study for construction of a highspeed railway linking the cities of Campinas, São Paulo and Rio de Janeiro. In the area of Cartography, the mapping of the State done by EMPLASA (Empresa Paulista de Planejamento Metropolitano S.A.) on a scale of 1:10,000 for the metropolitan regions of São Paulo, Campinas, Baixada Santista and São José dos Campos and 1:25,000 for other regions, is worthy of notice. Moreover, there is a special project, denominated Thematic and stimulated by the São Paulo State Foundation to Support Research - FAPESP, with the final aim of contributing to the GNSS infrastructure (Global Navigation Satellite System), for geodesic positioning and integration to science and technology. This project also seeks to collaborate with the investigations related to assessment of the geoidal model, systems of altitude and vertical monitoring of the earth's crust for an estimate of this component at mean sea level.

The aim of this work is to verify the contribution of gravimetric densification in the state of São Paulo, seeking the calculation of a geoidal model, and also its validation with the recent models of geopotential and the official Brazilian model (MAPGE02010) (Matos et al., 2011). Figure 1 shows the position of São Paulo State in relation to South America, and also the polygon that represents the area of calculating the geoidal model.

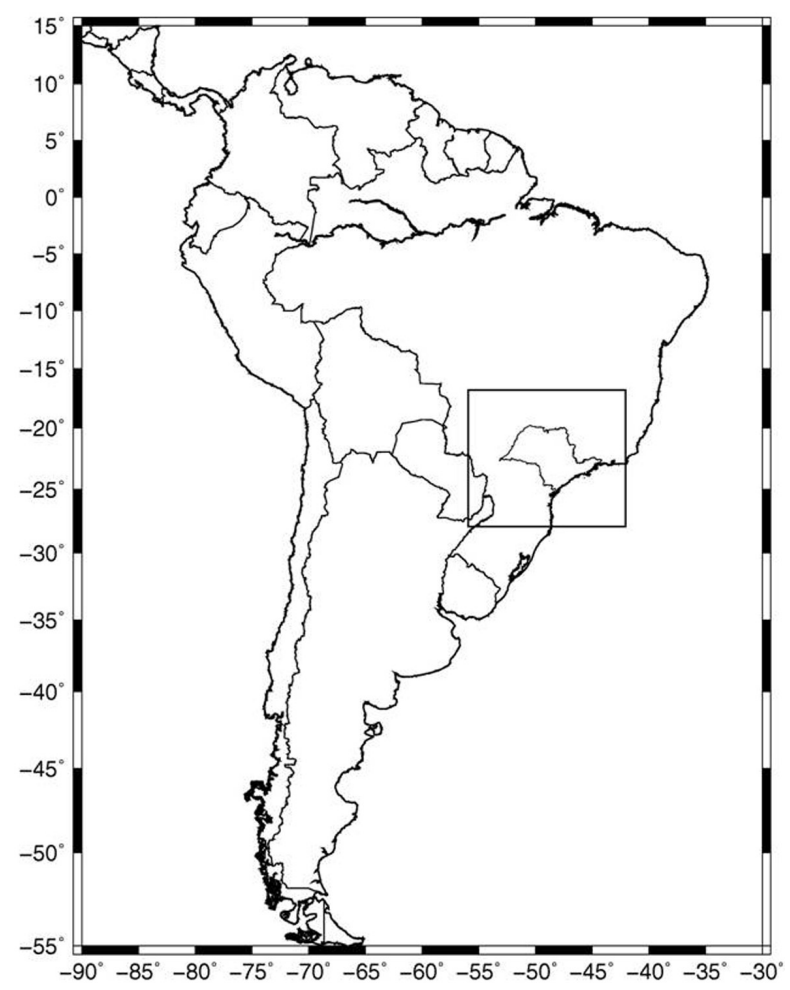

Figure 1 - Selected area for the geoidal model calculation.

\section{THE EARTH'S GRAVIMETRY}

The technique used to measure the acceleration of gravity $(g)$, in an absolute or relative manner over the entire surface of the earth is denominated gravimetry. In the absolute mode, the value $g$ is obtained directly at a station, whereas in the relative determination, the difference in $g$ is obtained from two stations (Gemael, 1999; Torge, 2001).

Before the advent of gravimeters, relative determinations were performed making use of pendulums. Spring gravimeters appeared in the first half of the last century. An elastic system holds in suspension a mass which is attracted with more or less intensity depending on the force of gravity at the location. A compensating bolt reestablishes the position of balance, which is defined by construction. Reestablishment of position is expressed by a 
reading which is subsequently transformed into units of acceleration (Blitzkow, 1996).

Technological progress has allowed the development of highly-sensitive apparatus, however, it has not been possible to attain great stability. With the passage of time gravimeters undergo variations in their elastic conditions, which is called drift, and must be corrected. Moreover, other factors must be examined with a certain frequency: sensitivity, correction of levels and calibration (e.g. Gemael, 1999; Blitzkow, 2003; Castro Junior, 2005). The development of electronic gravimeters was another technological contribution. In these, the operator does no more than level the equipment, while the other stages are performed automatically by means of internal software. Attention must be given to defining the initial parameters (coordinates, time zones, tide calculation) and if wrong these may compromise the survey. One disadvantage is that, like any other electronic equipment, it is subject to faults in its system. Starting from measurements of acceleration of gravity we can obtain gravity anomalies, reduce them to the geoid or to another surface and, applying the due transformation, arrive at the geoidal heights (Guimarães, 2010). Given the difficulty of obtaining gravimetric measurments over the entire surface of the earth, modifications were proposed the Stokes integral functions. Representation of the geoidal height in abbreviated form is expressed in the following manner (Blitzkow, 1996):

$$
N(\theta, \lambda)=N_{L}(\theta, \lambda)+\delta N_{L}(\theta, \lambda)
$$

where the term $N_{L}$ expresses the long wavelength component of the geoidal height and the term $\delta N_{L}$ the component of the shortest wavelength. The first term of the second member of expression 1 symbolizes geometrically the separation between the ellipsoid and the reference spheroid represented by the model of geopotential; the second term is the separation between the spheroid and the geoid, obtained from the gravimetric data (Fig. 2).

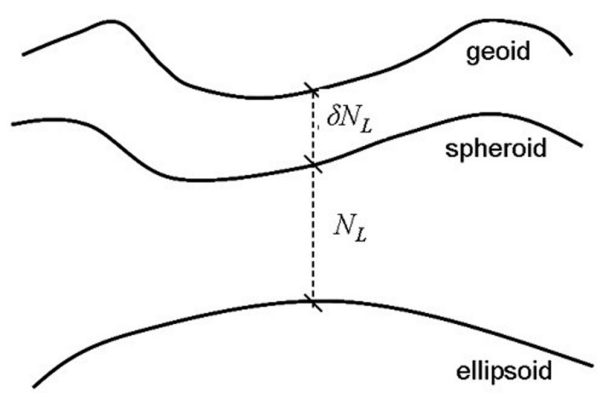

Figure 2 - Components of geoidal height.

Long wavelengths are calculated based on a model of geopotential, which means extending the series up to a degree and order $L$. The short wavelengths may be calculated by a modification to the Stokes integral, allowing it to be restricted to a cap, with radius $\psi_{0}$.

September 2008 saw the start of the Thematic project, and since then gravimetric campaigns have been carried out. Figure 3 a illustrates the distribution of the gravimetric stations in the state of São Paulo and surroundings until 2008. It is important to mention that several institutions collaborated with the data: the National Observatory, PETROBRAS, National Petroleum Agency and the IBGE. Figure $3 \mathrm{~b}$ portrays the data incorporated since the beginning of 2009. Making gravimetric measures in the surroundings of the state was decided on, going beyond it, given that calculating the geoidal heights using the modified integral entails having information on the acceleration of gravity at an average distance of $150 \mathrm{~km}$ from the point of calculation. In regions where the gradient of the geoidal height is greater, this called for spacing between the stations of $5 \mathrm{~km}$ and in the others, $8 \mathrm{~km}$.

The geoidal model of the state of São Paulo displays a resolution of 5'. Figure 4 depicts a grid of the same resolution, in which each square shaded in gray contains at least one gravimetric observation, which represents a coverage greater than $90 \%$. In the South of the state some gaps are found. In this case, densification proves unviable, as it is a hilly region, difficult to approach. In the surroundings of the state it is possible to affirm that the striping encompassing Paraná state displays total coverage, except in the mountainous region. The states of Mato Grosso do Sul and Minas Gerais display some empty spaces. São Paulo University (USP), in cooperation with the IBGE, intends to make efforts to fill in these gaps in the coming years.

\section{CALCULATION OF THE GEOIDAL MODEL}

The scheme for determination of the geoidal model (Fig. 5) may be assembled in five stages (Blitzkow et al., 2007):

1. Calculation of the free-air anomalies from the earth gravimetric data (geodesic coordinates, orthometric altitude and acceleration of gravity);

2. Calculating of the individual complete Bouguer anomalies, obtained from the free-air anomalies and correction for the spherical terrain effect, calculating these with mean values within 5" resolution. From the mean values we obtain the mean free-air anomalies;

3. Calculation of the Helmert gravity anomalies on the surface of the Earth. These are obtained from the sum total of the free-air anomaly, the direct topographical effect (DTE), 
(a)

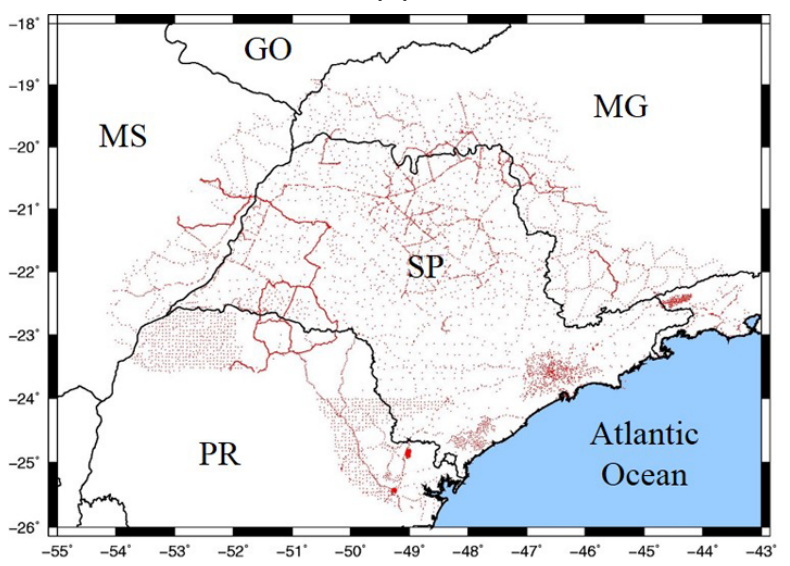

(b)

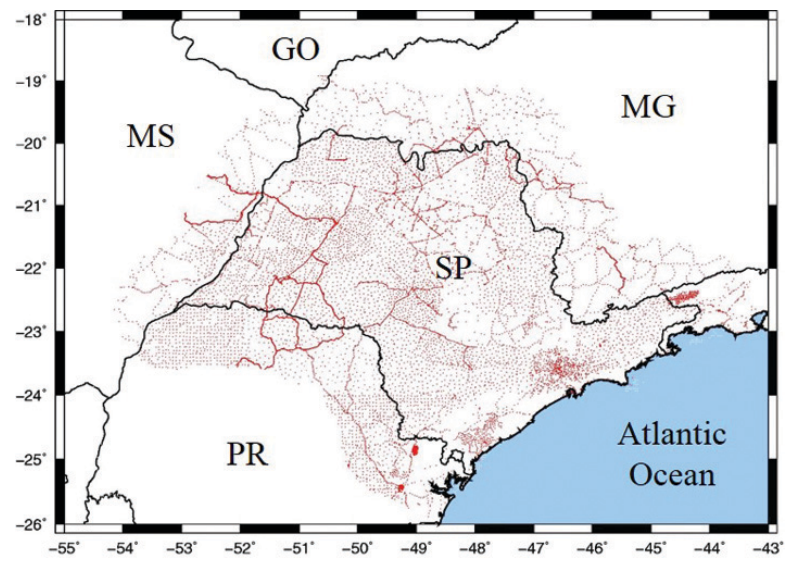

Figure 3 - (a) Gravimetric stations in 2008; (b) Gravimetric stations in 2011.

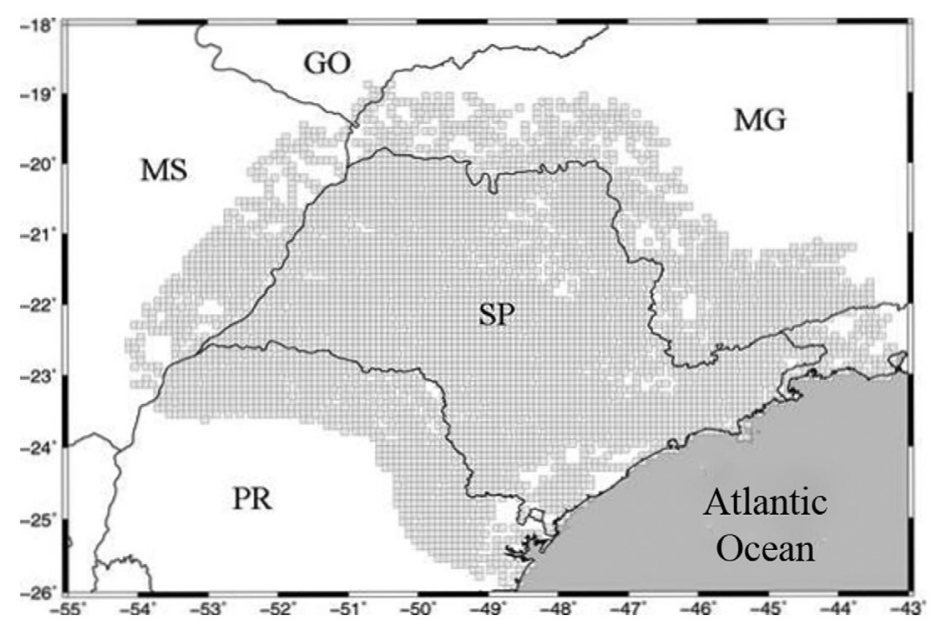

Figure $4-5$ ' squares of the gravimetric measurements.

the direct atmospheric effect (DAE) and the secondary indirect topographic effect (SITE) (Ellmann \& Vanicek, 2007);

4. Performing the modified Stokes integral, making use of the technique "remove-calculate-replace";

5. Addition of the primary indirect topographic effect (PITE) at the geoidal heights referred to a "fictitious geoid" denominated co-geoid (Martinec \& Vanicek, 1994; Martinec, 1998), to obtain the geoidal heights referred as the new geoid.

The SHGEO software, developed by the University of New Brunswick, Canada, was used to calculate the Helmert gravity anomalies (Ellmann, 2005a, 2005b). The Bouguer anomaly was calculated a priori for a digital model of 1' using a method of interpolation by the inverse of distance. Then, a 5 ' grid was created from the simple mean of the 1' values. The digital model of the terrain used was the SAM3_v2, with 3" resolution (Matos \& Blitzkow, 2008). This consists of using SRTM3 (Shuttle Radar Topography Mission) (Farr et al., 2007), although the geoidal heights of EGM96 (Earth Gravitational Model 1996) (Lemoine et al., 1998a; 1998b) used in this were replaced by ElGENGL04C (Forste et al., 2006). The void values were filled in from digital maps and from DTM2002 (Saleh \& Pavlis, 2002; Blitzkow et al., 2007). The mean free-air gravity anomalies in a grid of 5 ' over the continent were calculated using the mean Bouguer anomalies, the altitudes from the digital model of terrain with 5' resolution and mean correction of terrain. Over the ocean, mean anomalies were obtained using the FNSC08-GRA model from the Danish National Space Center with resolution of 1' (Andersen et al., 
2009). The technique of "remove-calculate-replace" consisted of removing from the mean gravity anomalies and the long wavelength component provided by EGM2008 (Pavlis et al., 2008), degree and order of 150 . This model is complete up to degree and order 2159 and contains additional spherical harmonic coefficients up to degree 2190 and order 2159. The Stokes integral was calculated, extending to a neighborhood $\psi=1.5^{\circ}$. Then, the long wavelength component from EGM08 was restored at geoidal height, using the same degree and order. Calculation of the integral was accomplished using the FTT technique (Fast Fourier Transform), with assistance from the FFTMOD program (Li \& Sideris, 1993), where modification of the Stokes nucleus is proposed by Featherstone et al. (1998). This modification (Meissl, 1971) proposes a simple subtraction of the value of the Stokes nucleus function in relation to the truncation distance allowing that the Fourier series of the truncation error converges to zero more quickly (Featherstone et al., 1998).

The expression of the modified Stokes integral for obtaining the geoidal heights (Ellmann \& Vanicek, 2007) is given by:

$$
\begin{aligned}
N(\Omega)= & \frac{R}{4 \pi \gamma_{0}(\phi)} \iint_{\Omega_{\psi_{0}}} S^{M}\left(\psi_{0}, \psi\left(\Omega, \Omega^{\prime}\right)\right) \\
& \times \Delta g\left(r_{g}, \Omega\right) d \Omega^{\prime} \\
& +\frac{R}{2 \gamma_{0}(\phi)} \sum_{n=2}^{M} \frac{2}{n-1} \Delta g_{n}^{h}\left(r_{g}, \Omega\right) \\
& +\frac{\delta V^{t}\left(r_{g}, \Omega\right)}{\gamma_{0}(\phi)}+\frac{\delta V^{a}\left(r_{g}, \Omega\right)}{\gamma_{0}(\phi)}
\end{aligned}
$$

where,

$$
\Delta g\left(r_{g}, \Omega\right)=\left(\Delta g^{h}\left(r_{t}, \Omega\right)-\sum_{n=2}^{M} \Delta g_{n}^{h}\left(r_{g}, \Omega\right)\right)
$$

The geocentric position $(r, \Omega)$ of any point is represented by the geocentric radius $r$ and by the pair of geocentric coordinates $\Omega=(\phi, \lambda) ; R$ is the mean radius of the Earth. On the right-hand side of the equality of expression 2, the first term is the Helmert residual co-geoid and the residual anomalies; $\Delta g\left(r_{g}, \Omega\right)$ is calculated by expression 3 where $\Delta g^{h}\left(r_{t}, \Omega\right)$ is the Helmert gravity anomaly referred to the surface of the earth (Vanicek et al., 1999).

As the reference field, with low degree and order, is removed prior to the Stokes integration (second term of expression 3), the contribution of the long wavelength must be added to the residual component of the geoidal height (the second term of the righthand side of expression 2). The sum total of the first two terms results in the Helmert co-geoid. The third term is the primary indirect topographical effect (Martinec, 1993) and the last term is the primary indirect atmospheric effect (Novak, 2000). Taking into account the indirect effects of the geoidal heights we obtain the quasi geoid.

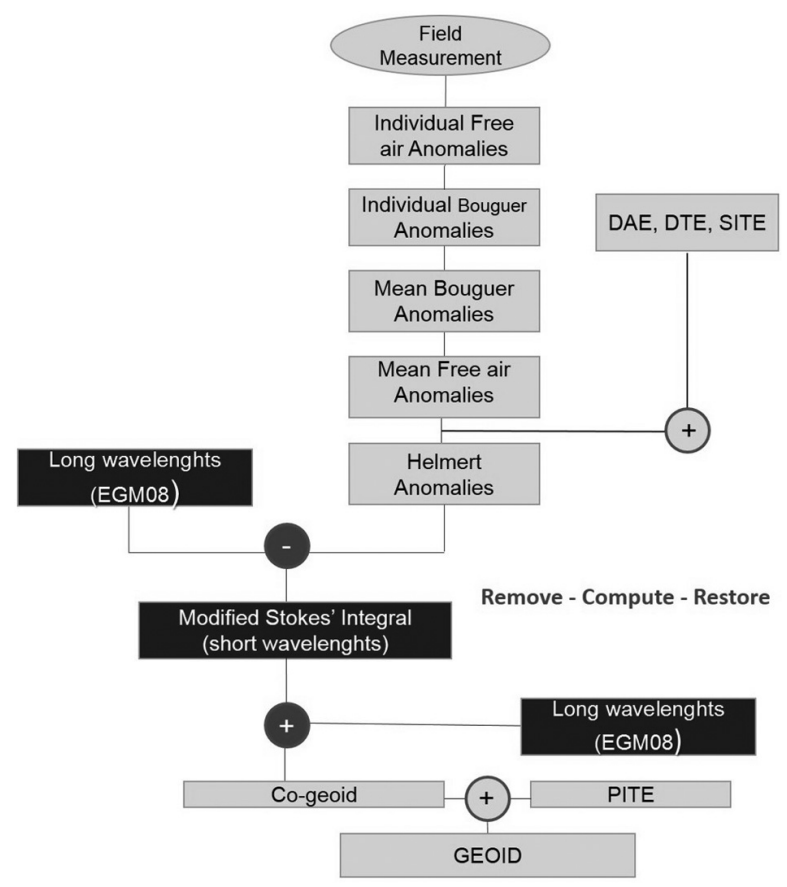

Figure 5 - Stages for the geoidal model calculation.

\section{VALIDATION OF THE GEOIDAL MODEL}

With a view to appraising the quality of the geoidal model of São Paulo state (Fig. 6) and analyzing the contribution of gravimetric densification, four validations were performed, and will be presented in this topic.

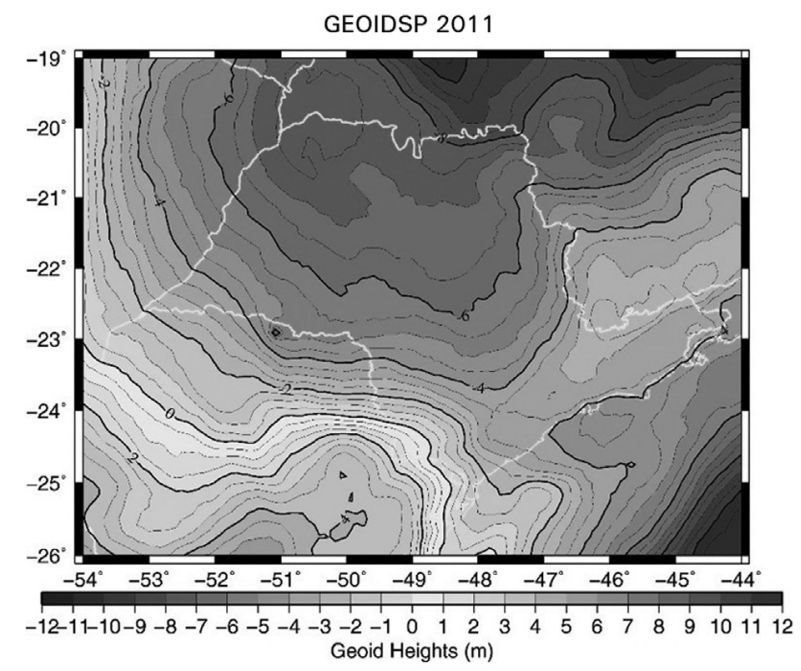

Figure 6 - Geoidal model of the State of São Paulo. 


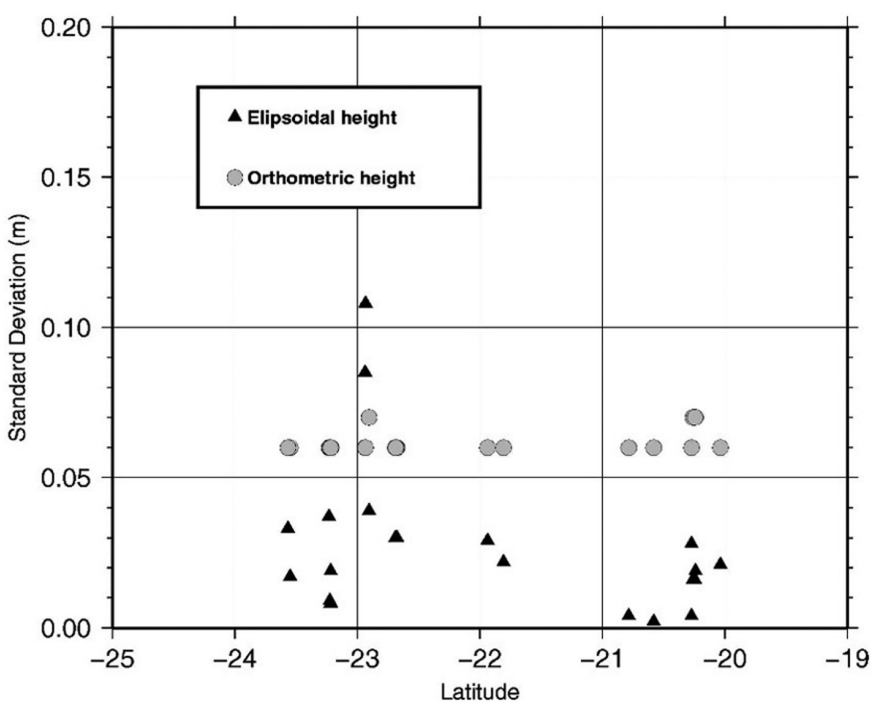

Figure 7 - Standard deviation of the orthometric and geodesic altitudes.

The geoidal model was compared with 170 level reference stations where GPS observations were conducted, hereinafter denominated GPS/RN. The orthometric altitudes were obtained by means of geometric levelling and the geoidal altitudes determined with geodesic GPS. Of this total, 133 stations belong to the USP Laboratory of Topography and Geodesy (LTG-USP) and they were provided by the following institutions: USP Institute of Astronomy, Geophysics and Atmospheric Sciences, SABESP (Sanitation Utility) and Companhia do Metropolitano de São Paulo (São Paulo subway). The accuracy of the geodesic altitude of these stations is in the order of $0.06 \mathrm{~m}$ (Sá \& Vieira, 2006); regarding the orthometric altitude there is no information on accuracy. The remaining 37 stations were provided by the IBGE, of which 26 are included in the most recent adjustment to the SGB altimetric network (IBGE, 2011). Figure 7 illustrates the standard deviations of the orthometric and geodesic altitudes of the IBGE stations. In terms of orthometric altitude, we find an accuracy of 0.06-0.07 $\mathrm{m}$, while the accuracy of the geodesic altitudes ranges from some millimeters to slightly over $0.10 \mathrm{~m}$.

Two geoidal models, GEOIDSP2008 and GEOIDSP2011, were determined with the same methodology, differing only the distribution of the gravimetric data presented in Figures $3 \mathrm{a}$ and $3 \mathrm{~b}$, respectively. The geoidal heights for both models were compared in absolute manner to the $170 \mathrm{GPS} / \mathrm{RN}$ points. The statistical summary is shown in Table 1.

In Table 1 we see that, after gravimetric densification, GEOIDSP2011 proves to be more consistent with the GPS/RN points than for the GEOIDSP2008 model. Figures 8a and 8b illustrate the statistic comparison in terms of histograms. In Fig- ure $8 \mathrm{~b}$ we see that the graph of normal distribution has a lower standard difference in relation to Figure $8 \mathrm{a}$ and that the greater concentration of points is in the interval of -0.2 to $0.2 \mathrm{~m}$.

Table 1 - Comparison between the geoidal heights and GPS/RN stations (meters)

\begin{tabular}{|c|c|c|c|c|}
\hline & Mean & $\begin{array}{c}\text { Standard } \\
\text { Difference }\end{array}$ & Max. & Min. \\
\hline GE0IDSP2008 & 0.16 & 0.22 & 0.64 & -0.36 \\
GEOIDSP2011 & 0.10 & 0.19 & 0.61 & -0.42 \\
\hline
\end{tabular}

Figures $9 \mathrm{a}$ and $9 \mathrm{~b}$ set out the differences between the GPS/ RN points and the two models in graphic terms. Based on the individual differences, a grid was generated with resolution of 30' using the method of bi-linear interpolation. The lighter colors represent the smallest differences. The largest differences between the 2008 and 2011 models are presented in the region of the Serra do Mar mountains (to the East and South of the State). It was found that the addition of data in this region helped in attaining the 2001 model showing greater consistency over the GPS/BM model than the 2008 model.

The second comparison refers to the geoidal heights from MAPGE02010 with those of the models obtained in this study. It should be stressed that the data collected in the gravimetric campaigns of 2009, used in the model GEOIDSP2011, were also employed in the calculation of MAPGE02010. Figures 10a and 10b illustrate the differences, while the statistics are shown in Table 2. 
(a)

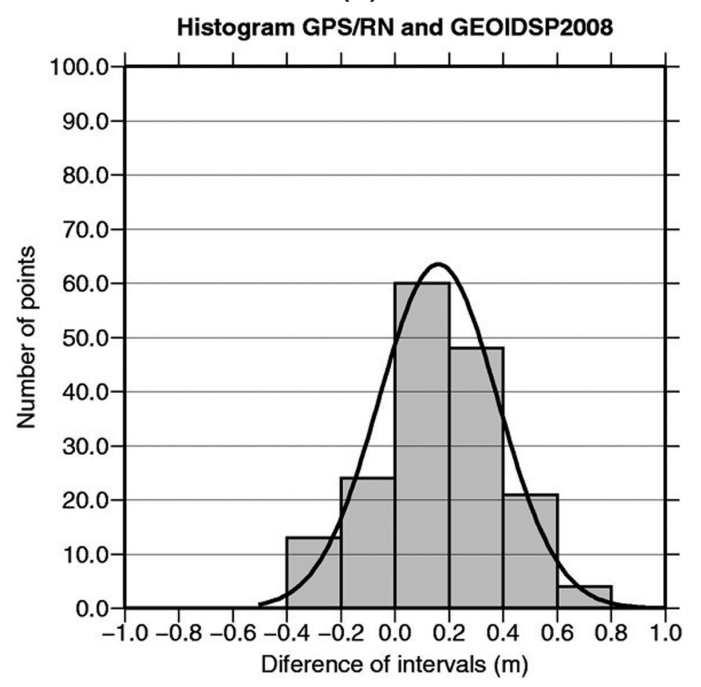

(b)

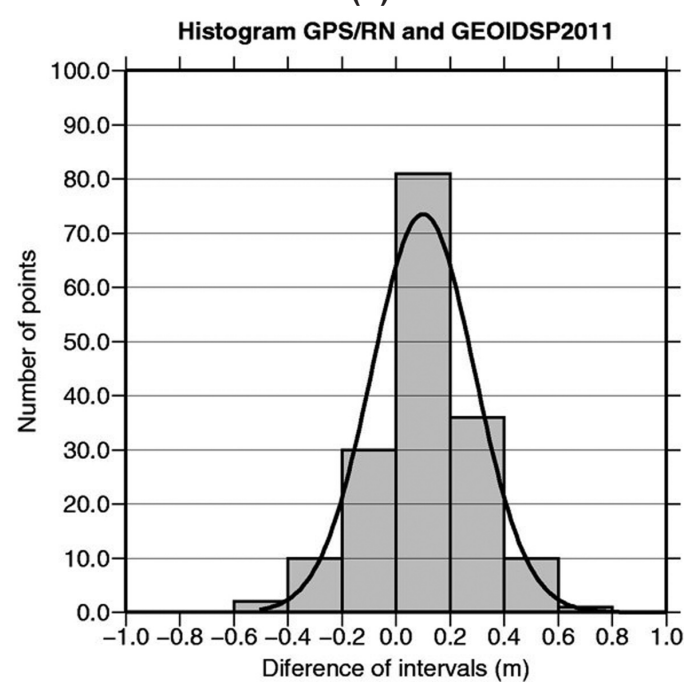

Figure 8 - (a) Histogram of GPS/RN and GEOIDSP2008; (b) Histogram of GPS/RN and GEOIDSP2011.

(a)

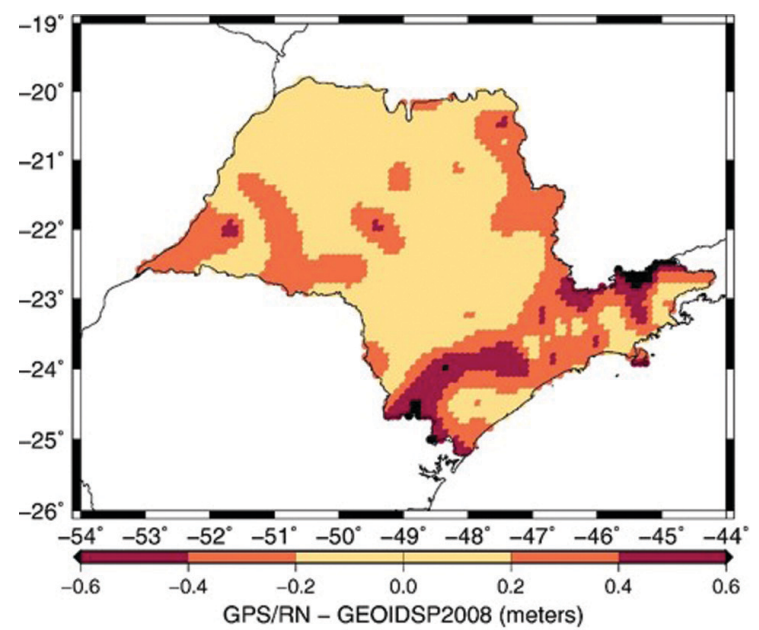

(b)

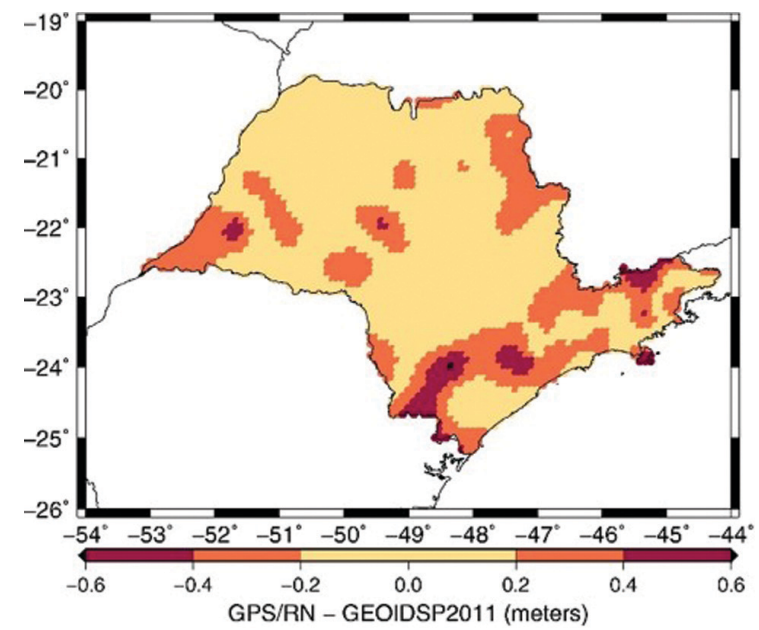

Figure 9 - (a) Difference, GPS/RN and GEOIDSP2008; (b) Difference, GPS/RN and GEOIDSP2011.

Table 2 - Difference in the geoidal heights between MAPGE02010 and the models GEOIDSP2008 and GEOIDSP2011 (meters).

\begin{tabular}{|c|c|c|c|c|}
\hline & Mean & $\begin{array}{c}\text { Standard } \\
\text { Difference }\end{array}$ & Max. & Min. \\
\hline MAPGE02010 - GEOIDSP2008 & 0.057 & 0.07 & 0.31 & -0.11 \\
MAPGE02010 - GEOIDSP2011 & 0.004 & 0.04 & 0.19 & -0.11 \\
\hline
\end{tabular}

Once again it is possible to note the benefits of the gravimetric measurements in the mountainous regions. The geoidal heights of the 2011 model prove to be more consistent with those of MAPGE02010 than the 2008 model. The standard difference of the more recent model is $0.04 \mathrm{~m}$, whereas in the previous model it was $0.07 \mathrm{~m}$.
The third validation consisted of comparing the geoidal heights derived from the GPS/RN stations with the anomalies of height of the most recent models of geopotential. The models used were: EIGEN-6C (Forste et al., 2011), G0C002S (Goiginger et al., 2011), GO_CONS_GCF_2_TIM_R2) (Pail et al., 2010) and EGM2008. MAPGE02010 was also used in the comparison. 
(a)

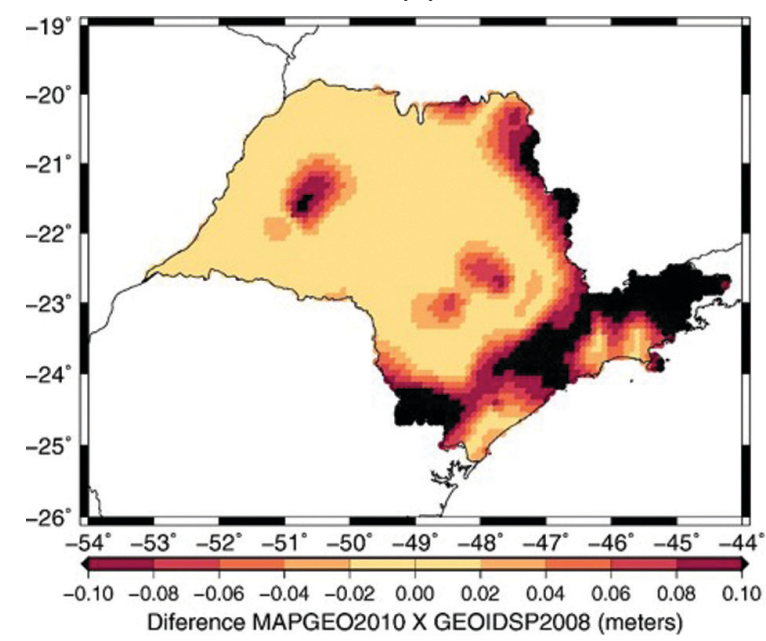

(b)

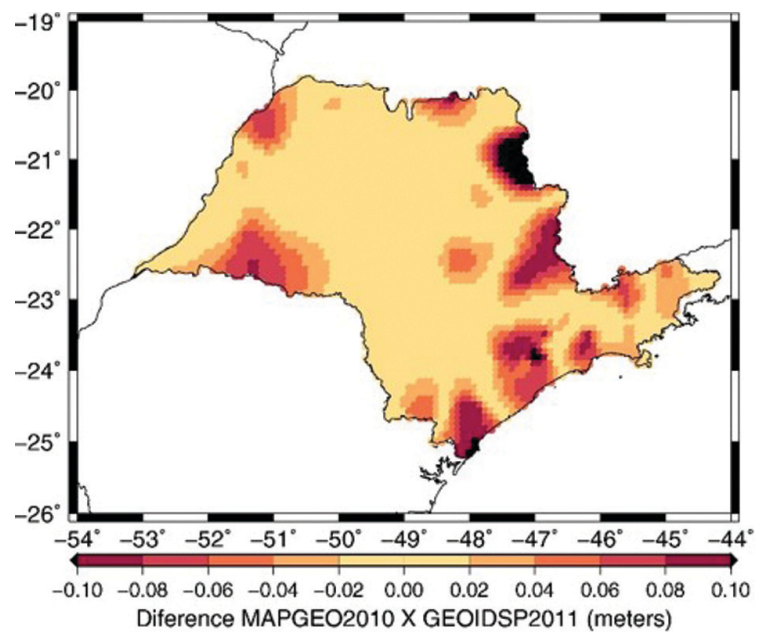

Figure 10 - (a) Difference of the geoidal heights (MAPGE02010 × GEOIDSP2008); (b) Difference of the geoidal heights (MAPGE02010 × GEOIDSP2011).

Table 3 - Statistical analysis of the absolute comparison of the GPS/RN points (meters).

\begin{tabular}{|c|c|c|c|c|}
\hline & Mean & $\begin{array}{c}\text { Standard } \\
\text { Difference }\end{array}$ & Max. & Min. \\
\hline GEOIDSP2011 & 0.10 & 0.19 & 0.61 & -0.42 \\
EIGEN-6C & 0.17 & 0.18 & 0.67 & -0.41 \\
GOC002S & 0.16 & 0.32 & 0.99 & -0.56 \\
G0_CONS_GCF2_TIM_R2 & 0.16 & 0.32 & 1.03 & -0.59 \\
MAPGE02010 & 0.10 & 0.19 & 0.61 & -0.45 \\
EGM2008 & 0.18 & 0.18 & 0.59 & -0.49 \\
\hline
\end{tabular}

EIGEN-6C contains the coefficients in series of spherical harmonic functions up to degree and order 1420. The model is a combination of data from the satellites GOCE (Gravity field and steady-state Ocean Circulation Explorer), GRACE (Gravity Recovery and Climate Experiment) and LAGEOS (Laser GEOdynamics Satellite), along with earth gravimetric data and altimetry by satellite. GOCO02S is a combined solution of the satellites GOCE, GRACE and CHAMP (Challenging Minisatellite Payload) and SLR (Satellite Laser Ranging) and has a degree and order of 250. The geopotential model G0_CONS_GCF_TIM_R2, degree and order 250, used data from the GOCE satellite and the TIM solution (Time-Wise Approach). EGM2008 similarly employed the combination of satellite (GRACE) data, satellite altimetry earth gravimetry. It has coefficients up to degree and order 2160.

The statistics (Table 3), indicate that models EIGEN-6C and GO_CONS_GCF_TIM_R2, calculated only with data from the space missions, display values in terms of standard difference in the order of $0.32 \mathrm{~m}$. In the other models, including MAPGE02010 and GEOIDSP2011, the difference was less than $0.20 \mathrm{~m}$. In terms of the mean, the results expressed by the geopotential models are in the order of 0.16 to $0.18 \mathrm{~m}$, whereas the values from GEOIDSP and MAPGE02010 did not exceed $0.10 \mathrm{~m}$. The histograms of the comparisons between the geoidal height and the height anomaly are illustrated in Figure 11.

The relative comparison was one more validation performed. In total, 61 pairs of points spaced between 20 and $50 \mathrm{~km}$ were selected. This interval allows an evaluation of the influence of short wavelengths. From the following expressions, it is possible to calculate the relative difference:

$$
\begin{gathered}
N_{G P S 1}-N_{G P S 2}=\Delta N_{G P S} \\
N_{G E O I D E 1}-N_{G E O I D E 2}=\Delta N_{G E O I D E}
\end{gathered}
$$

which is given by:

$$
\text { difrel }=\left(\Delta N_{G E O I D E}-\Delta N_{G P S}\right) / \text { Dist }
$$

The graphic analysis of GEOIDSP2011 is seen in Figure 12, and the statistical summary involving the used models is presented in Table 4. 

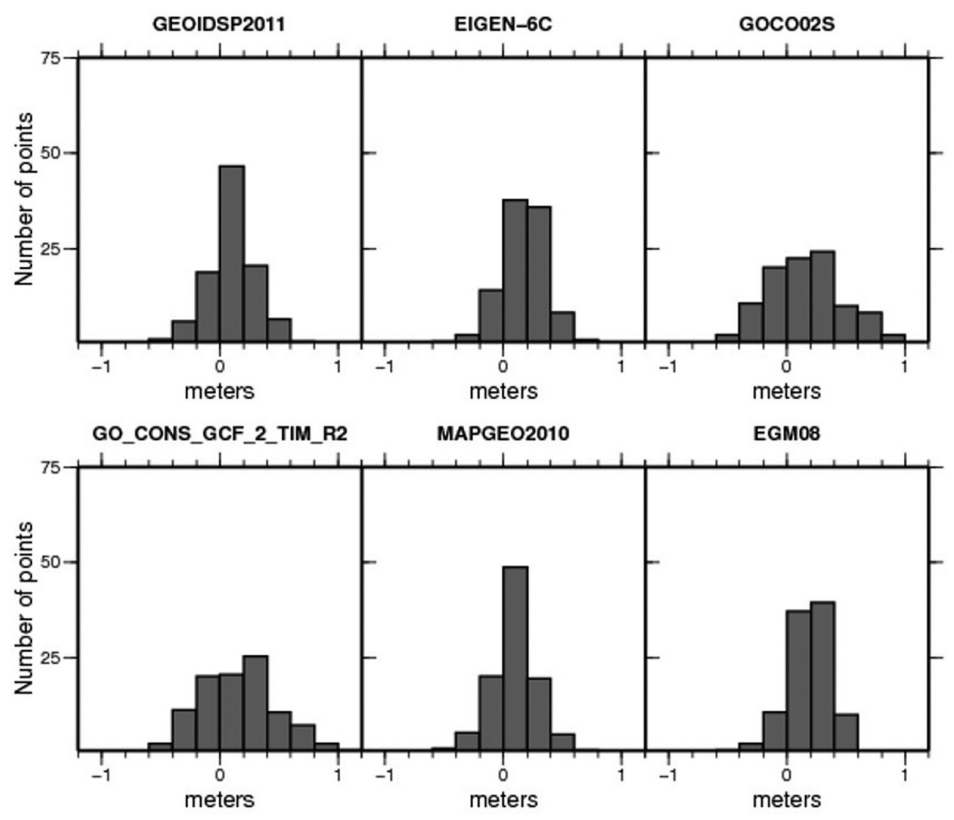

Figure 11 - Histograms of the comparisons of geoidal heights and height anomalies.

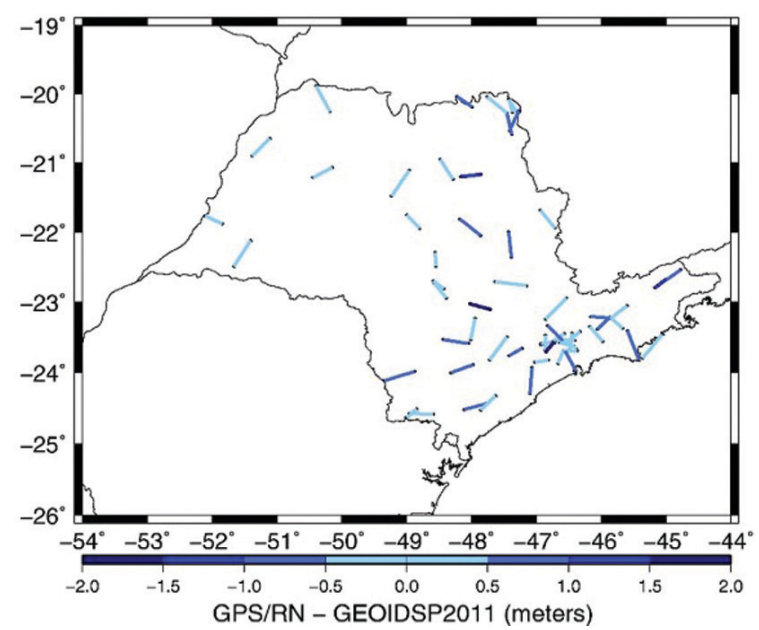

Figure 12 - Relative difference between GPS/RN and GEOIDSP2011.

Table 4 - Statistical analysis of the relative comparison of the GPS/RN points.

\begin{tabular}{|c|c|c|c|c|}
\hline Models & $\begin{array}{c}\text { Mean } \\
(\mathrm{cm})\end{array}$ & $\begin{array}{c}\text { Standard } \\
\text { Difference } \\
(\mathrm{cm} / \mathrm{km})\end{array}$ & $\begin{array}{c}\text { Max. } \\
(\mathrm{cm})\end{array}$ & $\begin{array}{c}\text { Min. } \\
(\mathrm{cm})\end{array}$ \\
\hline GEOIDSP2011 & 0.15 & 0.59 & 1.37 & -1.97 \\
EIGEN-6C & 0.19 & 0.58 & 1.44 & -1.82 \\
GOC002S & 0.11 & 1.17 & 3.06 & -2.56 \\
G0_CONS_GCF_2_TIM_R2 & 0.10 & 1.18 & 3.09 & -2.61 \\
MAPGE02010 & 0.16 & 0.59 & 1.40 & -1.82 \\
EGM2008 & 0.21 & 0.57 & 1.44 & -1.53 \\
\hline
\end{tabular}

Figure 12 shows $63.9 \%$ of the pairs with a difference between 0.00 and $\pm 0.50 \mathrm{~cm} / \mathrm{km}, 29.5 \%$ with values between \pm 0.50 $\pm 1.00 \mathrm{~cm} / \mathrm{km}$ and $6.60 \%$ above $\pm 1.00 \mathrm{~cm} / \mathrm{km}$. We note in Table 4 that the standard differences obtained for both the São Paulo model and also MAPGE02010 are close. The combined geopotential models (EIGEN-6C and EGM08) proved to be more consistent in relation to the GPS/RN points than the models that use only data derived from space missions.

\section{CONCLUSION}

The efforts of the gravimetric surveys addressing densification in the state of São Paulo and its surroundings have contributed to a better consistency of the geoidal model in relation to the GPS/RN points. This fact may be observed in Figures $9 a$ and $9 b$ where the main contribution is in the mountainous region of the state (east-south axis), where there was a shortfall in the gravimetric information. It is considered that the consistencies of the geoidal heights from the model GEOIDSP2011 with those from the GPS observations on the level reference stations is in the order of $0.19 \mathrm{~m}$.

Model GEOIDSP2011 showed better accuracy in relation to the geopotential models in the absolute and relative comparison. When compared to MAPGE02010, the results are practically equal. It should be stressed that $75 \%$ of the stations used in calculating the state model are also contained in the Brazilian 
model. The geopotential models EIGEN-6C and EGM2008 display consistency very close to that of the São Paulo geoid. This fact may be explained by the use of not only satellite data, but also by gravimetric data (earth, aerial and ocean) and by satellite altimetry. The same conclusion may be presented in relation to the relative comparison. In this latter, the São Paulo model displays better consistency than the geopotential models and results close to the MAPGE02010.

Field works will continue until the remaining gaps are filled, in particular in the state of Minas Gerais. At the end of densification, it is expected to calculate another geoidal model and compare it with those presented in this article.

\section{ACKNOWLEDGEMENTS}

The authors wish to thank Prof. Artur Ellmann (Tallin Technology University, Estonia), Prof. Dr. Peter Vanicek and Prof. Dr. Marcelo Carvalho dos Santos (University of New Brunswick, Canada). The activity performed received financial support from the Canadian government, through the Project Changing the National Geodesic Referential, which was coordinated by the Instituto Brasileiro de Geografia e Estatística (IBGE) and the University of New Brunswick (UNB), and sponsored by the Canadian International Development Agency (CIDA) through an international agreement with the Agência Brasileira de Cooperação (ABC). The State of São Paulo benefited from a distinct improvement in the distribution of gravimetric points through the Thematic Project "GNSS: investigations and applications in geodesic positioning, in studies related to the atmosphere and in precision agriculture", sponsored by FAPESP (Process: 2006/04008-2).

\section{REFERENCES}

ANDERSEN OB, KNUDSENP \& PHILIPPA AMB. 2009. The DNSC08GRA global marine gravity field from double retracked satel lite altimetry. Journal of Geodesy, 84: 191-199, doi 10.1007/s00190-009-0355-9.

BLITZKOW D. 1996. 0 problema do valor de contorno da geodésia: resultados práticos para a América do Sul. (Habilitations Theses) - Escola Politécnica, Universidade de São Paulo, São Paulo, 81 pp.

BLITZKOW D. 2003. Sistemas de altitudes e a determinação do geóide. Lecture Notes in Instituto Oceanográfico de la Armada (INOCAR). Guaiaquil, Ecuador.

BLITZKOW D, MATOS ACOC, CAMPOS IO, ELLMANN A, VANICEK P \& SANTOS MC. 2007. An attempt for an Amazon geoid model using Helmert gravity anomaly. Earth: our changing planet. In: IAG General Assembly at IUGG XXIV, Perugia Italia, July 2-13. CD-ROM.
CASTRO JUNIOR CAC. 2005. Contribuição ao estabelecimento de um sistema gravimétrico para a América do Sul. Master Dissertation Escola Politécnica, Universidade de São Paulo, São Paulo, 151 pp.

ELLMANN A. 2005a. SHGEO software packages-An UNB Application to Stokes-Helmert Approach for Precise Geoid Computation, reference manual I, 36 p. Available at:

http://gge.unb.ca/Research/GRL/GeodesyGroup/SHGeo_package/ Manual/SHGeo_manual」_v2.pdf. Access on: Sept. 05, 2011.

ELLMANN A. 2005b. SHGEO software packages-An UNB Application to Stokes-Helmert Approach for Precise Geoid Computation, reference manual II, 43 p. Available at: http://gge.unb.ca/Research/GRL/GeodesyGroup/SHGeo_package Access on: Sept. 05, 2011.

ELLMANN A \& VANICEK P. 2007. UNB application of Stokes-Helmert's approach to geoid computation. Journal of Geodynamics, 43: 200-213.

FARR TG, ROSEN PA, CARO E, CRIPPEN R, DUREN R, HENSLEY S, KOBRICK M, PALLER M, RODRIGUEZE, ROTH L, SEAL D, SHAFFER S, SHIMADA J, UMLAND J, WERNER M, OSKIN M, BURBANK D \& ALSDORF D. 2007. The Shuttle Radar Topography Mission. Reviews of Geophysics, 45, RG2004, doi: 10.1029/2005RG000183.

FEATHERSTONE W, EVANS J \& OLLIVER J. 1998. A Meiss--modified Vanícek and Kleusberg kernel to reduce the truncation error in gravimetric geoid computations. Journal of Geodesy, 72: 154-160.

FÖRSTE C, FLECHTNER F, SCHMIDT R, KÖNIG R, MEYER U, STUBENVOLL R, ROTHACHER M, BARTHELMES F, NEUMAYER H, BIANCALE R, BRUINSMA S, LEMOINE J-M \& LOYER S. 2006. A mean global gravity field model from the combination of satellite mission and altimetry/gravimetry surface data - ElGEN-GL04C. In: 2006 EGU General Assembly. Geophysical Research Abstracts Vol. 8 03462. Available on: http://www.geophysical-research-abstracts.net/gra_volume_8.pdf. Access on: Sept. 05, 2011.

FÖRSTE C, BRUINSMA S, SHAKO R, MARTY JC, FLECHTNER F. ABRIKOSOV O, DAHLE C, LEMOINE J-M, NEUMAYER H, BIANCALE R, BARTHELMES F, KÖNIG R \& BALMINO G. 2011. EIGEN-6 - A new combined global gravity field model including GOCE data from the collaboration of GFZ-Potsdam and GRGS-Toulouse. In: 2011 EGU General Assembly. Geophysical Research Abstracts Vol. 13, EGU20113242-2. Available on: http://www.geophysical-research-abstracts.net/ gra_volume_13.pdf. Access on: Sept. 05, 2011.

GEMAEL C. 1999. Introdução a Geodésia Física. Editora UFPR. Curitiba. 304 pp. ISBN: 8573350296.

GOIGINGER H, HOECK E, RIESER D, MAYER-GUERR T, MAIER A, KRAUSS S, PAIL R, FECHER T, GRUBER T, BROCKMANN JM, KRASBUTTER I, SCHUH WD, JAEGGI A, PRANGE L, HAUSLEITNER W, BAUR 0 \& KUSCHE J. 2011. The combined satellite-only global gravity field 
model G0C002S. Presented at the 2011 General Assembly of the European Geosciences Union, Vienna, Austria, April 4-8. CD-R0M.

GUIMARÃES GN. 2010. A altimetria e o modelo geoidal no estado de São Paulo. Master Dissertation. Escola Politécnica, Universidade de São Paulo, São Paulo, 119 pp.

IBGE. 2011. Ajustamento simultâneo da rede altimétrico de alta precisão do sistema brasileiro geodésico brasileiro. Relatório, Rio de Janeiro, 62 pp. Available on: < http://www.ibge.gov.br/home/geociencias/ geodesia/altimetrica.shtm>. Access on: Oct. 19, 2011.

LEMOINE FG, PAVLIS NK, KENYON SC, RAPP RH, PAVLIS EC \& CHAO BF. 1998a. New high-resolution model developed for Earth's gravitational field, EOS, Transactions, AGU, 79, 9, March 3, 113, 117-118.

LEMOINE FG, KENYON SC, FACTOR JK, TRIMMER RG, PAVLIS NK, CHINN DS, COX CM, KLOSKO SM, LUTHCKE SB, TORRENCE MH, WANG YM, WILLIAMSON RG, PAVLIS EC \& RAPP RH. 1998b. The development of the joint NASA GSFC and the National Imagery and Mapping Agency (NIMA) geopotential model EGM96, NASA/TP-1998206861. National Aeronautics and Space Administration, Maryland, USA.

LI Y \& SIDERIS M. 1993. Minimization and estimation of geoid undulation errors. Bulletin Géodésique, 68: 201-219.

MARTINEC Z. 1993. Effect of lateral density variations of topographical masses in view of improving geoid model accuracy over Canada. Final Report of the contract DSS No. 23244-2-4356. Geodetic Survey of Canada, Ottawa.

MARTINEC Z. 1998. Boundary-value problems for gravimetric determination of a precise geoid. Lecture notes in earth sciences, 73 , Springer.

MARTINEC Z \& VANÍCEK P. 1994. Direct topographical effect of Helmert's condensation for a spherical approximation of the geoid. Manuscripta Geodaetica, 19: 257-268.

MATOS ACOC \& BLITZKOW D. 2008. Modelagem Digital de Terrenos (MDT) de 3" para a América do Sul (projeto de Pos-Doc). Available on: http://www.ptr.poli.usp.br/ltg/proj/proj26.htm. Access on: Sept. 05, 2011.
MATOS ACOC, BLITZKOW D, GUIMARÃES GN, LOBIANCO MCB \& COSTA SMA. 2012. Validação do MAPGE02010 e comparação com modelos do geopotencial recentes. Boletim de Ciências Geodésicas, v. 18, n. $1,101-122$ p.

MEISSL P. 1971. Preparations for the numerical evaluation of secondorder Molodenskii-type formulas. Columbus, Dep. of Geodetic Science and Surveying. Ohio State University, Report 163.

NOVÁK P. 2000. Evaluation of gravity data for the Stokes-Helmert solution to the geodetic boundary-value problem. Technical Report No. 207, Department of Geodesy and Geomatics Engineering, University of New Brunswick, Fredericton.

PAIL R, GOIGINGER H, MAYRHOFER R, SCHUH WD, BROCKMANN JM, KRASBUTTER I, HÖCK E \& FECHER T. 2010. Global gravity field model derived from orbit and gradiometry data applying the time-wise method. In: ESA Living Planet Symposium. Proceedings... Bergen, Norway. 28 June-2 July 2010, ESA SP-686.

PAVLIS NK, HOLMES SA, KENYON SC \& FACTOR JK. 2008. An earth gravitational model to degree 2160. Geophys. Res. (Abstract 10, EGU2008-A-01891, 2008, Ref ID: 1607-7962/gra/EGU2008-A-01891, EGU General Assembly). Available on:

< http://earth-info.nga.mil/GandG/wgs84> Access on: Oct. 19, 2011.

SÁ NC \& VIEIRA C. 2006. Rede GPS do estado de São Paulo: aprimoramento de modelos geoidais e apoio básico local. Relatório científico final FAPESP (Processo: 99/012691-9) Instituto de Astronomia, Geofísica e Ciências Atmosféricas, Universidade de São Paulo, São Paulo, 90 pp.

SALEH J \& PAVLIS NK. 2002. The development and evaluation of the global digital terrain model DTM2002. In: $3^{\text {rd }}$ Meeting of the International Gravity and Geoid Commission, Thessaloniki, Greece.

TORGE W. Geodesy. 3 ed New York, USA: Ed. Walter de Gruyter, 2001.

VANÍCEK P, HUANG J, NOVÁK P, PAGIATAKIS SD, VÉRONNEAU M, MARTINEC Z \& FEATHERSTONEWE. 1999. Determination of the boundary values for the Stokes-Helmert problem. J. Geodesy, 73: 160-192. Available on: http://cat.inist.fr/?aModele=afficheN\&cpsidt=1787191. Access on: Sept. 05, 2011. 


\section{NOTES ABOUT THE AUTHORS}

Gabriel do Nascimento Guimarães. Graduate in Cartographic Engineering from the Universidade Estadual Paulista Julio de Mesquita Filho (2007). Master in Transport Engineering, sub area of Space Information, from the Polytechnic School of Universidade de São Paulo (2010). Doctor in Transport Engineering, sub area of Space Information, from Polytechnic School of Universidade de São Paulo (2013). Currently is professor of the Geography Institute of the Universidade Federal de Uberlândia. Experienced in the area of Geosciences, with emphasis on Geodesy, active principally in the following matters: gravimetric surveys, calculation of geoidal model, geopotential models, among others.

Ana Cristina Oliveira Cancoro de Matos. Bachelor's Degree in Mathematics from the Universidade Presbiteriana Mackenzie (1982), Master in Space Science/Radioastronomy and Solar Physics from the National Institute of Space Research (1987). Doctor in Transport Engineering, sub area of Space Information, from the Polytechnic School of Universidade de São Paulo (2005). Currently is assistant researcher at the Polytechnic School of Universidade de São Paulo. Experienced in the area of Astrophysics, Radio-astronomy and Geosciences, with emphasis on Physical Geodesy, active principally in the following matters: digital terrain model, calculation of geoidal model, geopotential models, study of variation of water level over time, among others.

Denizar Blitzkow. Graduate in Education, Mathematics course, from the Universidade Federal do Paraná (1970), Master in Geodesic Sciences from the Universidade Federal do Paraná (1973), and Doctor in Geophysics from Universidade de São Paulo (1986). Currently is a retired professor of the Department of Transport Engineering at the Polytechnic School of Universidade de São Paulo. Experienced in the area of Geosciences, with emphasis on Geodesy, active principally active in the following matters: geoid, gravimetry, satellite positioning, Cartesian references and altitude systems. 